\title{
POSSIBLE MECHANISMS OF THE EXCLUSION OF JOHNSON GRASS BY TALL GRASS PRAIRIES
}

\author{
Submitted to the Faculty of the Graduate College of Oklahoma State University \\ in partial fulfillment of the requirements for the Degree of Master of Science \\ May 1972
}

\author{
Marilyn A. Semtner \\ E-mail: msemtner@aol.com
}

Keywords: Johnsongrass, exclusion, control, prairies, allelopathy

\begin{abstract}
Historically, plant distribution typically has been studied with the purpose of learning why a species grows and survives where it does; but why a species does not survive in a particular habitat has rarely been studied, although it may be just as important. According to the US Department of Agriculture, Johnsongrass [Sorghum halepense (L.) Pers.; formerly Johnson grass] is listed as an agricultural pest in most states south of the $42^{\text {nd }}$ parallel. Control of Johnsongrass in agricultural fields involves various labor intensive cultural, mechanical, and chemical means. Release of a bio-control agent has not been suitable for intensively cropped areas. An agriculturally important weed and prominent member of early stage secondary succession, Johnsongrass is not present in later stages of prairie succession. Various environmental factors (biotic and abiotic) that might be involved in restricting Johnsongrass survival were examined in this research. In two sites in Oklahoma, soil conditions were found to be more favorable for survival and growth of Johnsongrass in undisturbed prairie than in the disturbed areas in which Johnsongrass was found vigorously growing. However, even when its rhizomes were introduced into mature prairie, Johnsongrass did not thrive. In laboratory and field trials, presence of the living dominant prairie grasses or leachate from living or dead leaf blades seemed to influence growth and survival of Johnsongrass rhizomes. The prairie grasses, little bluestem [Schizachyrium scoparium (Michx.) Nash] and Indian grass [Sorghastrum nutans (L.) Nash], seem to play a similar allelopathic role in restricting the growth of Johnsongrass to outside of the prairies. Looking at this past study might lead to new methods for the future. (Semtner 2012)
\end{abstract}

\section{INTRODUCTION}

Plant distribution has typically been studied with the intent of discovering why a species grows where it does. Early studies of Johnson grass [Sorghum halepense (L.) Pers.; currently Johnsongrass] took this approach. Introduced about 1830 from Turkey, Johnson grass has vigorously and rapidly spread from the Atlantic coast to central Texas and has been recently reported in low wet places in California (Munz 1963). It is known as a sun-adapted grass that grows well at high temperatures (Ahlgren 1956).
Although it has some value as forage, it has been and is regarded as a serious weed. Adapted to a variety of habitats, Johnson grass was reported to be an aggressive invader of such disturbed habitats as abandoned and cultivated fields and roadsides, as well as rich alluvial river bottoms. Producing large tenacious rhizomes, it is extremely difficult to eradicate. Due to its invasion of cultivated fields, many attempts have been made to control it, especially by chemical means. Control methods were directed mostly 
toward destruction of the rhizomes. Workers in chemical control have included Leonard and Harris (1952), McWhorter (1961), Nester (1967), Hicks and Fletchell (1967), Wiese (1968), Millhollon (1970), and Kleifeld (1970).

Secondary succession occurs in abandoned fields and other places where the vegetation is damaged or destroyed. Those plants appearing first give way and are replaced by other species. Ultimately the climax or stable vegetation consists of species that replace themselves when their life span ends. Booth (1941) divided secondary succession in old fields in central Oklahoma into 4 stages, based on species present: (1) weeds, (2) annual grasses, (3) perennial bunch grasses, and (4) climax prairie. He surveyed the vegetation present in the annual grass and bunch grass stages. No mention was made of finding Johnson grass in either of those stages. Abdul-Wahab and Rice (1967) considered Johnson grass a prominent member of the weedy stage and definitely absent from the later stages. Their observations, however, were probably made under quite different circumstances than Booth's (1941). Observations made during the current study indicate that Johnson grass flourishes in disturbed roadsides. In continually disturbed roadsides, succession seemed to be arrested in the weedy stage.

Betz and Cole (1969) noted that undisturbed native prairie resisted invasion of both weeds and woody plants. Weaver (1968) indicated that prairies were virtually closed communities with neither a great wave of immigration nor emigration. Invaders were excluded. Invasion by weeds and/or woody plants has been considered a sign of disturbance by Clements and Shelford (1939), Petty and Jackson (1966), Weaver (1968), and Black, Chen, and Brown (1969). The lack of weed and tree invasion of undisturbed prairies generally has been credited to interactions of environmental factors, abiotic and biotic, that maintain the prairie community. The more common reasons given were climate, moisture, soil, temperature, life form and competition [fire - Vogl (1964), water - Hylander (1966), soil and water - Weaver (1968), climate and water - Grossman, Louise and Hamelot (1969), moisture and fire - Sears (1969), no one main factor by multi-influences Costello (1969), fire and climate deLaubenfels (1970), and climate and drainage - Vesey-Fitz Gerald (1970)]. Despite widespread observation of and comment upon the failure-of-invasion phenomenon, it has been studied very little in its own right.

My observations indicated that Johnson grass was neither an invader nor a component of undisturbed prairies, yet it might be abundant a few centimeters away in a disturbed roadside. Causes of this apparent exclusion of Johnson grass by the undisturbed prairie were unknown and unstudied. The aim of my research was to explore various possible mechanisms of the exclusion of Johnson grass by tall grass prairies.

Many factors might be involved in the exclusion of Johnson grass from undisturbed prairies. The latitude probably was influential in limiting the original spread of Johnson grass across the countryside. Wheeler and Hill (1957) reported that Johnson grass grew abundantly in the vicinity of prairies in North America, south of latitude $40^{\circ}$, under a wide range of climatic conditions. Ahlgren (1956) reported that Johnson grass grew vigorously as a perennial, south of the $35^{\text {th }}$ parallel, from the Atlantic Coast to central Texas. Further northward, winter killing occurred. At the latitude of central Oklahoma, $36^{\circ}$, Johnson grass behaves as a perennial grass. Hull (1970) found that the rhizomes exhibited little or no cold hardiness at any time of the life cycle. The rhizomes were intolerant of freezing temperatures and were killed. Johnson grass, therefore, presumably was restricted from northern prairies due to the severity of the winters. 
Southern prairies are subject to high summer temperatures with periods of low rainfall. Beal (1887) reported Johnson grass as an aggressive perennial grass able to withstand great heat and severe drought. Standing water was found to kill it. Ahlgren (1956) felt that abundant moisture, supplied by rainfall, stream overflow, or irrigation was beneficial but not essential for growth of Johnson grass. The climate of southern prairies generally would not be restrictive to growth of Johnson grass.

Grasses and grass communities tend to monopolize the ground against intruders. Hylander (1966) felt that grasses pre-empted living space by producing rhizomes and stolons. Tiller production dominated the surrounding area and discouraged intrusion of weeds. Weaver (1968) felt that any reproduction, spread, or establishment of weeds in prairies would need to be vegetative through rhizomes or tillers. The network of prairie plants' roots and rhizomes in the soil was so dense that "foreign" seedlings could not become established. The spread of Johnson grass by rhizome initiation has been well documented by many researchers. Hitchcock (1922) reported that Johnson grass propagated readily by seed and strong rhizomes. Anderson, Appleby, and Wescloh (1960) showed that rhizome initiation occurred 4 to 5 weeks following seedling emergence and was well developed after 6 to 7 weeks. McWhorter (1961) found that plants grown from seed produced 212 feet of rhizomes in 152 days of growth. Evans (1964) reported that rhizome growth in many grasses occurred only under long day conditions. With Johnson grass, both flowering and rhizome growth can occur together. Johnson grass flowering was accelerated by short days.

Competition for some necessary resource such as light, water, or nutrients has been commonly supposed to help the prairie resist invaders. Clements and Shelford (1939) reported that, in enclosures, annual grasses steadily disappeared under competition by perennial grasses. Black et al. (1969) measured the efficiency of carbon assimilation in many species and concluded that more efficient species were better competitors than less efficient ones. He proposed that permanent pastures lacked weed problems because the efficient perennial grasses did not allow less efficient weeds to establish. He found Johnson grass to be an efficient species. Abdul-Wahab and Rice (1967) said that Johnson grass had excellent abilities to compete for light, minerals, and water.

The concept that one plant can influence the growth of another is well known. Competition for some necessary resource is but one such influence. Another type of influence is allelopathy, which involves chemical substances released from one plant that harms another. Substances potentially involved in allelopathy may be liberated from plants by (a) leaching of foliage by rain, (b) volatilization from foliage, (c) leaching from fallen material, and (d) root exudation (Tukey 1969). Risser (1969), in a review of competitive relationships among plants, concluded that plant interactions due to allelopathy should be separated from competition.

Pickering (1917) stated that the formation of toxins by one plant that have harmful effects on other plants or on itself was a common phenomenon. Benedict (1941) showed that dried roots of bromegrass (Bromus inermis Leyss.) were inhibitory to the growth of bromegrass seedlings. A sod-bound condition resulted, due to the inhibition, with vigorous growth on the edges and stunted growth in the center of a stand of bromegrass. Bonner (1950) felt that numerous species, as yet unstudied, may produce substances toxic to one or more species, and that associations or non-associations of species due to production of chemical compounds might not be uncommon occurrences. Cooper and Stoesz (1931) found that Helianthus 
pauciflorus Nutt. ( $=\mathrm{H}$. rigidus) had an autotoxic action which inhibited or retarded growth of its own seedlings within the center of a stand. Vigorous individuals were confined to the periphery. Curtis and Cottam (1950) reported that the antibiotic and autotoxic effects of $H$. panciflorus were due to a substance derived from decomposition of old rhizomes. They felt that, based on preliminary observations, Antennaria parlinii Fernald (=A. fallax), Eurybia macrophylla (L.) Cass. (=Aster macrophyllus), and Erigeron pulchellus Michx. might produce similar acting substances.

Muller (1966) suggested that allelopathy could be a significant factor in plant succession of many kinds of vegetation. Muller et al. (1964) showed that the distribution pattern of annual grassland species in Santa Barbara County, California, was influenced by volatile growth inhibitors produced by Salvia leucopbylla Greene. In 1966, he reported that several aromatic shrubs of southern California produced phytotoxic terpenes which inhibited establishment of seedlings of a wide variety of species some distance from the shrubs. Further evidence of the toxic suppression of herb understory growth by shrubs was given by Muller et al. (1968).

Booth (1941), in his work on secondary succession in central Oklahoma, reported that the weed stage lasted only 2-3 years and that the climax grasses required 30 years or more to reinvade. Both the shortness of the weedy stage and the slow invasion by climax grasses are puzzling. Rice, Penfound, and Rohrbaugh (1960) tried to account for the slow return of climax grasses in abandoned fields by rate of seed dispersal and mineral nutrition. The rate of succession could not fully be explained by seed dispersal and mineral nutrition. Rice (1964) found widespread occurrence of inhibition of nitrogen-fixing and nitrifying bacteria by many weedy species including Johnson grass. As a result of this inhibition, a lower nitrogen level was maintained in the soil.
Parenti and Rice (1969) concluded that the first (weedy) stage was rapidly replaced by Aristida oligantha Michx. because several of the important pioneer species such as Helianthus annuus L., Sorghum halepense, and Chamaesyce maculata (L.) Small (=Euphorbia supina) produced toxins inhibitory to seedlings of many species of the first stage but not to $A$. oligantha. Several species of stage one eliminated species of that stage by chemical inhibition. A. oligantha invaded next because it was not inhibited by the substances toxic to pioneer species and was able to grow in soil too low in minerals to support species later in succession. $A$. oligantha was found to produce substances inhibitory to nitrogen-fixing and nitrifying bacteria (Rice 1964). This inhibition probably caused the longer persistence of the annual grass stage. The species of the perennial bunch grasses have higher nitrogen requirements (Rice et al. 1960).

The influence of prairie mulch or litter has not been extensively investigated. Weaver and Fitzpatrick (1934) reported that accumulations of mulch retarded growth in the spring. The soil warmed more slowly with the mulch due to reduced insolation. Weaver and Rowland (1952) experimented with growth of tall grass prairie species with and without the presence of prairie mulch. They found that the prairie with heavy litter cover had little to no understory growth. The prairie grasses that produced the litter grew better themselves with removal of the thick build-up of litter. The grasses involved included little bluestem and Indian grass. They felt the mulch was suffocating the plants. The lack of understory was attributed to the weight of the litter and decreased light being detrimental to seedling development. The seedlings would lack enough food reserve, unless they had large seeds, to grow through and above the litter. No reason was given for the limited growth of rhizomes or tillers by dominant grasses. Friend (1966) and Mitchell (1953a, b) showed that low light intensity decreased 
tiller numbers in ryegrass (Lolium L. spp). Vogl and Bjusted (1968) and Ehrenreich and Aikman (1963) concluded that litter build-up in undisturbed prairies caused lower soil temperatures, delayed growth in the spring, and reduced yields of little bluestem, big bluestem, and Indian grass.

Muenscher (1939) reported a number of species of wild and cultivated plants to be capable of producing hydrocyanic acid, also called prussic acid, a highly poisonous substance. Johnson grass was one of many cyanogenic plants. Huffman, Cathy, and Humphrey (1963) and Kingsburg (1965) reported Johnson grass to be a pest of cultivated fields with an undesirable characteristic of forming cyanide in certain stages of development. Abdul-Wahab and Rice (1967) showed that Johnson grass produced several chemicals inhibitory to other plants that resulted in pure stands of Johnson grass by the inhibition of other early invaders of abandoned fields. The chemicals were isolated and identified. The chemicals were found to have no or little affect on plant species that occur later in succession. Substances inhibitory to nitrogen-fixing and nitrifying bacteria were also produced (Rice 1964).

Some plants have been reported that influence the presence and/or growth of Johnson grass. Penfound, Jennison, and Shed (1965) reported the replacement of a Johnson grass population by a vine-forb community. An increase of climbing bean [Strophostyles helvola (L.) Elliott], an herbaceous, leguminous vine, occurred at the expense of Johnson grass. They concluded that climbing bean destroyed Johnson grass by climbing up the flowering culms, weighing them down, and preventing growth by shading. Bennett and Merwine (1964) found that planting legumes with Johnson grass would enhance growth of the latter for the first 2 years due to increased fertility and nitrogen in the soil. White clover (Trifolium repens L.), however, offered more "competition" to Johnson grass establishment and no gain resulted. Wheeler and Hill (1957) recommended sowing legumes with Johnson grass, if desired, for pasture. The legumes checked the tendency of Johnson grass to become sod-bound. Hitchcock (1922) reported that to utilize a Johnson grass-infested field, alfalfa should be sown. He felt that alfalfa would smother out most of the Johnson grass.

Recently, a few cases have been reported where the presence or absence of prairie grasses determined the presence of other species. Odum (1971) and Harper (1964a) concluded that the distribution and abundance of a species can be modified by the presence of associated species. Sagar and Harper (1961) showed that the presence and nature of grass communities played an important role in determining the presence or absence of weedy Plantago L. spp. and in limiting the size of the Plantago population. The Plantago spp. did not occur naturally within the grass community but would grow if the grasses were removed through some disturbance. Putwain and Harper (1970) concluded from their work that the grasses were mainly responsible for limiting the population size of the sorrels (Rumex acetosa L. and $R$. acetosella L.).

In my search for possible mechanisms of the exclusion of Johnson grass by an undisturbed prairie, various possibilities were suggested. The determining influence might be abiotic or biotic. Therefore, physical factors which might differ between the undisturbed prairie and a Johnson grass stand were explored. Many aspects of the soil were tested, including organic matter, texture, water content, and water retention ability. The effect of shading on Johnson grass growth was studied. The possibility that the prairie grasses were influencing the growth of Johnson grass was also examined. Both field and laboratory studies were utilized in an effort to determine the source of the exclusion of Johnson grass by an undisturbed, tall grass prairie. 


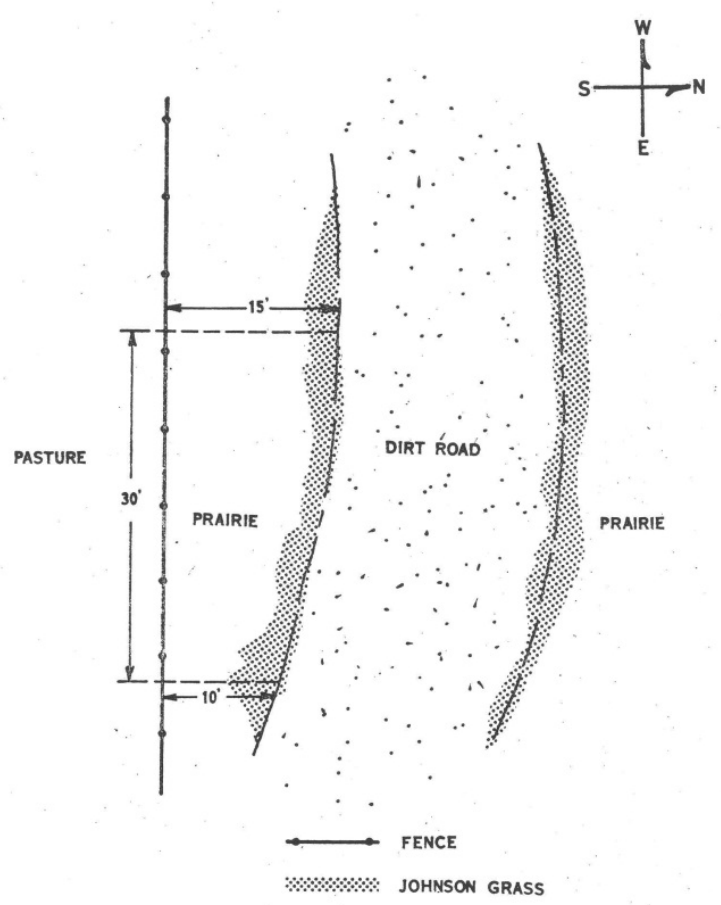

Figure 1 Blackwell Field Site near Lake Carl Blackwell, Payne County, Oklahoma

\section{DESCRIPTION OF FIELD SITES}

Two field sites were chosen in western Payne County, Oklahoma. Each consisted of a stand of Johnson grass adjacent to a prairie in good condition.

\section{Blackwell Site}

The first site was $1 / 2$ mile south of Lake Carl Blackwell. From here on, this site will be referred to as the Blackwell site. Solid stands of Johnson grass grew abundantly in the shallow ditches along both sides of a dirt road. The ditches were made some years ago and recently had been only slightly disturbed. The road was frequently graded, so Johnson grass was continually found reinvading the road from the edge (Figure 1). Although Johnson grass was continually spreading into the roadway, no spread was evident into the prairie on the opposite side.
Due to a curvature of the dirt road away from a fence, a small stand of prairie was protected from grazing. This protected area had been grazed previously, but was recovering well at the time of the study. The most prominent grasses were little bluestem [Schizachyrium scoparium (Michx) (=Andropogon scoparius)], Indian grass [Sorghastrum nutans (L.) Nash], silver bluestem [Bothriochloa saccharoides (Sw.) (=A. saccharoides)], and brome (Bromus L. spp.). Also present were small numbers of forbs, especially ones belonging to the Leguminosae and Compositae.

\section{Preserve Site}

A second site on the Oklahoma State University Ecology Preserve was selected. From here on, this site will be referred to as the Preserve site. The Preserve is located 9 miles west of Stillwater, Oklahoma, on the south side of State Highway 51 and is about 2 miles southwest of the Blackwell site. The relative placement of Johnson grass and prairie and causes were similar to those of the Blackwell site. This site was later partially destroyed by road maintenance work. The prairie within the Preserve, which remained undamaged, was used in field experiments described later.

\section{METHODS AND MATERIALS}

\section{Soil Analysis}

Soils may be responsible for vegetative distribution patterns. The exclusion of Johnson grass from undisturbed prairies could be influenced by soil characteristics. Various physical properties of the soil were explored to try to detect differences between the prairie soil and the Johnson grass soil.

\section{Organic Matter}

Organic matter (OM) was measured as an indicator of disturbance. The assumption was that the lower the $\mathrm{OM}$, the more 
disturbance the soil had experienced. OM was used to determine whether the soils in which Johnson grass and the prairie plants grew could be classified as disturbed. Johnson grass is usually associated with disturbed habitats.

Soil samples were taken from both the Blackwell and Preserve sites. Samples from the Blackwell site consisted of one from within a stand of Johnson grass and one from within the prairie. Samples from the Preserve were from 2 different areas within the prairie, differing in the amount of plant litter present.

Similar procedures were used to collect all the soil samples. A shovel was used to remove living plants off the surface and scrape off the top $2 \mathrm{~cm}$ of litter and soil. Samples were collected from the approximately $2-22 \mathrm{~cm}$ soil depth and consisted of pooled soil from 3 such pits. The soil was placed in appropriately labeled cardboard boxes and removed to the laboratory. After the soil was air dried in the Agronomy Department soil drying room for 24 hours, it was sieved through a \#10 sieve. The OM analysis was done by the Soil and Water Service Laboratory of the Agronomy Department at Oklahoma State University.

\section{$\mathrm{pH}$}

Determination of soil $\mathrm{pH}$ was made using a Corning Research $\mathrm{pH}$ meter (model 12) with equal parts by weight of air dry soil and distilled water. Soil samples were collected as previously described. Three replications were run with each soil type.

\section{Particle Density}

The particle densities were found using a pycnometer, following procedures described by Black (1965). Soil samples were collected as previously described and three replications were run.

\section{Soil Texture}

A mechanical analysis of soil was conducted to determine the percentage of sand, silt, and clay particles. The hydrometer method as described by American Society for Testing and Materials (1964) was followed. Soil from a depth of 2-22 cm, collected as previously described, was used, as that was the region that most new roots and rhizomes occurred. Three replications of both soil types were analyzed.

\section{Soil Moisture}

Plant growth is influenced greatly by the amount of soil moisture present. During June and July 1970, soil moisture was determined regularly to detect any differences in soil moisture between the prairie and the Johnson grass stand. Soil moisture was measured by the gravimetric method (American Society for Testing and Material 1958). Soil core samples were taken during June and July 1970 from the $2-22 \mathrm{~cm}$ soil depth. Three transects of samples were made at the Preserve site and 5 at the Blackwell site. The transects ran from the Johnson grass stand into the prairie. Three cores were taken in the Johnson grass stand and 2 in the prairie per transect. The top 2 $\mathrm{cm}$ of the soil core were discarded. The remainder of the core was divided into 2 parts, $2-12 \mathrm{~cm}$ and $12-22 \mathrm{~cm}$ depth. These segments were immediately placed in aluminum cans, sealed, and returned to the laboratory.

\section{Soil-Water Content under Different Tensions}

The amount of water retained by soils at a specific pressure was measured using a porous membrane, as described by Black (1965). Soil-water contents at pressures of $0.1,0.5,1,10$, and 15 bars were measured. Disturbed, air-dry soil was used with 2 replications per tension, per soil type. Johnson grass and prairie soils were collected as previously described from the Blackwell site. 


\section{Plant Material}

Whenever living plants were needed for experiments, Johnson grass rhizomes were collected along the dirt road adjacent to the Blackwell site. McWhorter (1961) found that plants from rhizomes grew more rapidly than plants from seeds. Hull (1970) did not detect any natural dormancy in single node rhizome pieces harvested at any time of the year. Hence, rhizomes were collected fresh as needed. Due to poor germination of local Johnson grass seeds, only rhizomes were used in the experiments.

Rhizomes were dug and placed in plastic bags. Field collected rhizomes were cut with clippers into segments containing one node. The soil in which the Johnson grass rhizomes were growing was very sandy and was easily brushed off the rhizome pieces. Rhizomes were used as soon after collection as possible.

\section{Experiments}

\section{Seed Germination}

Tests were run to determine the germination percentage of local Johnson grass seeds to decide the feasibility of using seeds as well as rhizomes in future experiments.

Seeds were collected several times from the areas of both field sites in 1970 and 1971. Germination tests were conducted with fresh and after-ripened (6-month and 1 -year) seeds. Several tests were conducted according to procedures given by Tester and McCormick (1969) with 5 replications of 10 seeds per treatment. Johnson grass seeds, fresh and 6 months after-ripened, were (a) pre-chilled for 5 days at $10^{\circ} \mathrm{C}$, (b) prechilled for 7 days at $10^{\circ} \mathrm{C}$, or (c) left at room temperature. Incubation was in the dark at room temperature. The experiment was subsequently repeated with 3 variations: (a) treated with 5 percent Clorox and rinsed thoroughly with several rinses of distilled water, (b) soaked in tap water for 5 days before pre-chilling, and (c) not treated. Germination was checked daily. A total of 450 seeds were used.

Taylorson and McWhorter's (1969) prechilling experiment was also tried. The procedure was to expose the seeds to 2 weeks at $10^{\circ} \mathrm{C}$ followed by 2 hours of $35^{\circ} \mathrm{C}$ and germination at $20^{\circ} \mathrm{C}$ in darkness. Fresh, 6-month, and 1-year-old after-ripened seeds were used with 5 replications of 10 seeds pre-treatment, for a total of 150 seeds. Germination was recorded daily.

Germination tests were also run with fresh and 6-month-old after-ripened seeds in soil from within a prairie and a Johnson grass stand. The soil was collected and prepared as previously described.

Commercial river sand was used as a control. Each soil type was placed in separate Petri plates. Twenty seeds were used per replication and there were 3 replications per soil type. Tap water was used to keep the soil moist. Germination was at $20^{\circ} \mathrm{C}$ in the dark. The objective of the experiment was to determine whether soil type influenced germination of Johnson grass seeds.

\section{Soil Preference in a Laboratory Situation}

Soils were collected from within a prairie and a Johnson grass stand near the Blackwell site, and Johnson grass planted in them to determine whether the growth of its rhizomes might be influenced by soil type. The vegetation, litter, and top $2 \mathrm{~cm}$ of soil were removed with a shovel. Soil was dug up from the 2-22 cm depth and placed in standard nursery flats lined with newspaper. The soil was sieved to remove any plant parts, rhizomes, roots, etc. Flats of commercial river sand were used as controls. Three replications of each substrate with 50 rhizome pieces per flat were made on February 19, 1971.

All flats were regularly tap watered, and the number of new plants emerging and total emergence per flat were recorded every other day for 41 days. No dry weights were 
taken because the plants in the soil from the Johnson grass stand were damaged by disease near the end of the experiment. A statistical analysis was made of the emergence data to determine whether Johnson grass emerged differently in any soil type relative to the others.

\section{Growth in Disturbed and Undisturbed Field Plots}

Field growth of Johnson grass from rhizomes was studied to determine if it would grow and survive in the prairie if manually planted. Rhizomes were planted under 2 conditions: disturbed (modified) and undisturbed (natural). In the disturbed plots, a $23 \mathrm{~cm}$ cube of soil was dug up, turned, mixed, and sieved to remove any plants and litter present. Any neighboring prairie plants that might lean over the plot were trimmed back. Five rhizome segments were planted per plot. Rhizome segments were placed approximately 4-6 cm deep.

In the non-disturbed plots, simple slits, $6 \mathrm{~cm}$ deep, were made in the ground with a shovel. One rhizome segment was planted in each of 5 slits per plot. No plants or litter were removed. Care was taken to avoid disturbance as much as possible. In each of the plots, the 5 rhizome pieces came from 2 or 3 different rhizomes. The procedure was repeated in a Johnson grass stand and prairie at the Blackwell site and in the prairie at the Preserve. Due to the smaller size of the Blackwell site, only 4 replications of each treatment were made in the prairie and 2 in the Johnson grass stand. Plot locations were randomized.

Eight replications were made of each treatment with 2 replications per treatment on each of the 4 transects in the prairie at the Preserve. Alternating the treatments among the subplots, each transect contained 4 subplots, $150 \mathrm{~cm}$ apart. Transect \#1 was made in a section of the Preserve prairie that was similar to that of the prairie in the Blackwell site. In both, grass litter was light. Open spaces existed between plants where bare soil could occasionally be seen. Along transects \#2-4, deeper within the Preserve prairie, tall grass prairie was in good condition. Tall, thick stands of Indian grass and little bluestem were growing. Plants were close together with a thick layer of litter on the ground. No bare ground could be seen.

A total of 140 rhizome segments were planted. Soil at planting was moist. Soil temperatures were within a range of $13-26^{\circ}$ $\mathrm{C}$ at the $7.5 \mathrm{~cm}$ depth and $14-22^{\circ} \mathrm{C}$ at 15 $\mathrm{cm}$ depth. This was slightly below the optimal $30^{\circ} \mathrm{C}$ for the maximum growth of the dominant prairie grasses and Johnson grass but well within the range for good growth. All planting was done on May 10, 1971.

Observations were made weekly to determine emergence and survival of Johnson grass. All surviving plants were harvested on September 20, 1971, and dry weights determined. Due to the extremely low numbers of plants recovered in September, no statistical analysis was conducted.

\section{Interference Experiment}

Many ecology textbooks and papers contain statements to the effect that weeds cannot compete with prairie plants. This has generally been accepted as the reason many possible invaders were excluded from the prairies. The assumption was that weeds were not efficient or successful in competing for some resource (light, water, or minerals) against the prairie plants. This statement is questionable in the case of Johnson grass. Johnson grass reportedly had excellent ability to compete for light, water, and minerals (Abdul-Wahab and Rice 1967). Black et al. (1969) showed both the dominant prairie grasses and Johnson grass to be efficient $\mathrm{CO}_{2}$ fixing species and concluded that both were good competitors.

One resource that plants generally compete for is light. A box experiment was conducted to determine the effect of 6 
different conditions. These were (1) control - full sunlight, (2) light shading - 70 percent of full sunlight obtained by 2 layers of white cheese cloth, (3) medium shading - 60 percent of full sunlight obtained by 6

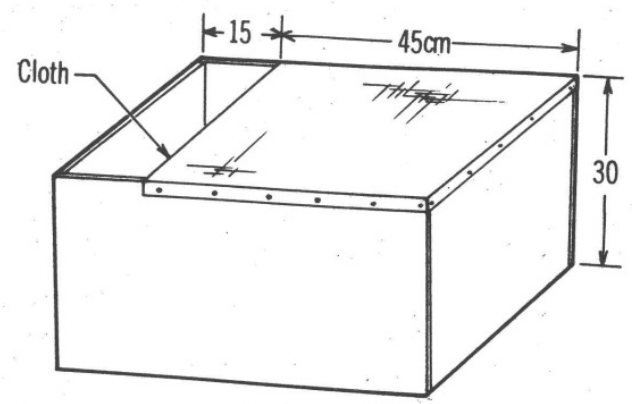

A. SHADE COVERING

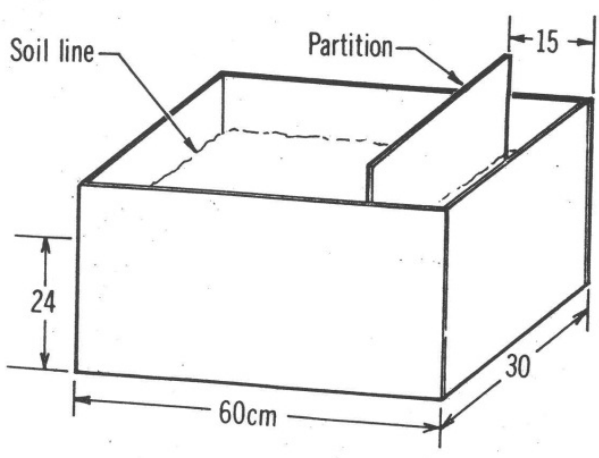

B. INTERFERENCE

Figure 2 Box designs for the interference experiments

layers, (4) heavy shading - 18 percent of full sunlight by a tightly woven cotton cloth, (5) litter mulching - 18 percent of full sunlight with prairie litter, and (6) aerial influence with prairie grasses. A light meter was used to measure the light intensity in the field at ground level to determine the amount of shading used in the boxes. In field measurements, prairies with heavy build-ups of litter had light values down to 2 percent of full sunlight, though amounts this low were not used in any experiment.
Wood boxes were built, each $30 \times 60 \mathrm{~cm}$ x $30 \mathrm{~cm}$ deep, in which the experimental plants were grown. Drainage slits were left in the bottom. The soil used was a ratio of 2 parts nursery soil and 1 part commercial sand. The cloth covers were stretched across $3 / 4$ of the boxes, approximately $6 \mathrm{~cm}$ above the soil level (Figure 2). Five Johnson grass rhizome segments, from 2 or more different rhizomes, were planted per box, under the shaded areas.

Prairie litter from the Ecology Preserve was collected in January, 1971 and stored in large paper bags in the laboratory until used. The litter was laid on top of the soil in the experimental boxes in amounts similar to those found in a healthy tall grass prairie with a normal build-up of litter. The litter was leached with tap water on the boxes twice weekly for a month before the rhizomes were planted.

Prairie plants were collected from the Blackwell area by randomly digging up intact clumps of prairie vegetation. Mainly, little bluestem and Indian grass were collected while dormant in early March, 1971. The clumps of prairie plants were planted in the large ends of 3 boxes and allowed to become established (see Figure 2). The previously described dirt-sand mixture was used to fill in around the prairie plants and the empty small ends. A partition was placed in the soil to divide the roots and prevent prairie plant roots from becoming established in the smaller section. After the Johnson grass plants in the smaller section had emerged, the partition was removed to alow the roots to intermingle.

The boxes were kept outdoors and were positioned in a completely randomized block design. All plants were subject to the same temperature and wind. The boxes were regularly watered. Three replications per treatment were made. The rhizome segments were planted August 25, 1971 and allowed to grow until September 30, 1971. Dry weight per plant was determined. A statistical analysis, using a hierarchial design 
to compare average dry weight per plant per treatment was performed.

\section{Effect of Plant Leachate on Growth}

The hypothesis was proposed that the prairie grasses might be producing some substance inhibiting the growth of Johnson grass. It was possible that the green leaves were producing and releasing the substance, or that release was upon the death of the leaf blade. Hence, 2 separate leachates were made: (1) fresh green leaves and inflorescences of little bluestem and Indian grass, and (2) old prairie litter. In nature, any leaching would be passive due to falling rain, dew, etc., so the leaves were leached in distilled water without any grinding. Plant material was leached by soaking with distilled water for 1 hour at a ratio of $10 \mathrm{~g}$ of plant material per $100 \mathrm{ml}$ of distilled water. The leachate was made fresh as needed, every 6 to 8 days. Leachate was stored in the dark at room temperature for periods not longer than 3 days.

Commercial river sand was used to fill standard nursery flats. Four replications per treatment with 50 Johnson grass rhizome segments per flat were planted on September 20,1971. The flats were arranged in a partial random block design in the greenhouse. Each flat was watered with approximately $800 \mathrm{ml}$ of leachate per week until October 19, 1971. For the remainder of the experiment until November 10, 1971, the plants were watered with tap water. The experiment was continued with tap water to determine if any effect on growth due to the leachate was permanent or temporary. The height of the individual plants after 29 days was recorded. The emergence per flat was recorded for 51 days.

\section{RESULTS AND DISCUSSION}

\section{Soil Analysis}

Several factors of the soil were examined to determine if these might be responsible for the exclusion of Johnson grass by the prairie.

\section{Organic Matter}

Organic matter (OM) was tested as an indicator of disturbance. Soils sampled from the prairie had consistently and considerably higher levels of OM than the Johnson grass soil (Table I). The higher OM levels in the prairies would make the prairie soil more favorable to plant growth and root development. There is no reason to doubt that the organic matter level present in prairies would encourage Johnson grass growth rather than restrict it.

\section{$\mathrm{pH}$}

Some plants are known to grow better in acidic or alkaline soils. Distribution of these species is influenced by soil $\mathrm{pH}$. Johnson grass, with its wide distribution, would not seem to be greatly influenced by the soil $\mathrm{pH}$. To determine if prairie soil $\mathrm{pH}$ was different from and thus possibly detrimental to Johnson grass growth, the soil $\mathrm{pH}$ of the prairie and Johnson grass sites was tested (see Table I). No significant $\mathrm{pH}$ differences were found. Soil $\mathrm{pH}$ would not be considered a factor restricting the growth of Johnson grass.

\section{Particle Density}

The particle density was determined mainly as a reference due to its influence on soil mass (see Table I). The difference between the 2 soil types was not enough to affect the soil texture greatly. The small differences in particle density would not be influential in determining the distribution of Johnson grass.

\section{Soil Texture}

Johnson grass has been reported to thrive in fine sandy loam and not grow well in deep sandy soils (Archer and Bunch 1953). The prairie soil did not appear to be a deep sandy soil, but texture analysis was performed (Table II). The prairie soil had 
more silt and slightly more clay, but less sand than the disturbed Johnson grass soil. Physically, the prairie soil would appear to favor the growth of Johnson grass more than the disturbed soil it occupies.

Table I Characteristics of 2 different soils at the $2-22 \mathrm{~cm}$ depth

\begin{tabular}{|c|c|c|c|c|c|}
\hline Location & Soil area & $\begin{array}{c}\mathrm{OM}^{\mathrm{a}} \\
\%\end{array}$ & $\mathrm{pH}^{\mathrm{b}}$ & $\begin{array}{l}\text { Particle }^{c} \\
\text { density }\end{array}$ & $\begin{array}{l}\text { Litter } \\
\text { covering }\end{array}$ \\
\hline \multirow{2}{*}{ Blackwell } & $\begin{array}{l}\text { Johnson } \\
\text { grass } \\
\text { stand }\end{array}$ & 0.5 & 6.2 & 2.54 & Very little \\
\hline & Prairie & 2.8 & 6.0 & 2.45 & $\begin{array}{l}\text { Light to } \\
\text { medium }\end{array}$ \\
\hline \multirow{2}{*}{ Preserve } & $\begin{array}{l}\text { Prairie } \\
\text { transect \#1 }\end{array}$ & 2.5 & 6.2 & & $\begin{array}{l}\text { Light to } \\
\text { medium }\end{array}$ \\
\hline & $\begin{array}{l}\text { Prairie } \\
\text { transect \#2-4 }\end{array}$ & 3.1 & 6.1 & & Thick \\
\hline \multicolumn{6}{|c|}{${ }^{a}$ Organic matter, no replications } \\
\hline 3 replication & & & & & \\
\hline
\end{tabular}

Table II Soil particle size analysis for 2-22 $\mathrm{cm}$ depth at the Blackwell site

\begin{tabular}{|c|c|c|c|c|c|}
\hline \multirow{2}{*}{ Soil source } & \multicolumn{4}{|c|}{ Percentage } & \multirow{2}{*}{ Soil type } \\
\hline & Rep. & Sand & Silt & Clay & \\
\hline \multirow{2}{*}{$\begin{array}{l}\text { Johnson } \\
\text { grass } \\
\text { stand }\end{array}$} & 1 & 75 & 9 & 16 & \multirow{3}{*}{ Sandy loam } \\
\hline & 2 & 81 & 6 & 13 & \\
\hline \multirow{4}{*}{ Prairie } & 3 & 79 & 6 & 15 & \\
\hline & 1 & 69 & 14 & 17 & \multirow{3}{*}{$\begin{array}{l}\text { Sandy loam } \\
\text { to } \\
\text { Sandy clay loam }\end{array}$} \\
\hline & 2 & 60 & 21 & 19 & \\
\hline & 3 & 63 & 19 & 18 & \\
\hline
\end{tabular}




\section{Soil Moisture}

Although the precipitation received by the prairie and the roadside, separated only by a few centimeters, was similar, differences in soil moisture might occur. Considerable variation existed between samples within each soil type, separated by a few centimeters. The variation among samples was great enough so that no large differences could be detected between soil types (Table III, Figure 3). The small differences in the soil moisture in June and July between the prairie soil and disturbed soil would not be enough to account for the presence or absence of Johnson grass.

Table III Average soil moisture in prairie and Johnson grass soils at 2 depths in 1970

\begin{tabular}{|c|c|c|c|c|}
\hline \multirow{2}{*}{ Location } & \multirow{2}{*}{ Date } & \multirow{2}{*}{ Level } & \multicolumn{2}{|c|}{ Percent moisture } \\
\hline & & & Johnson grass & Prairie \\
\hline \multirow[t]{14}{*}{ Blackwell } & \multirow[t]{2}{*}{ June 9} & $\mathrm{~T}$ & 13.0 & 16.5 \\
\hline & & $\mathrm{L}$ & 14.7 & 13.2 \\
\hline & \multirow[t]{2}{*}{ June 16} & $\mathrm{~T}$ & 10.3 & 9.6 \\
\hline & & $\mathrm{L}$ & 12.1 & 11.5 \\
\hline & \multirow[t]{2}{*}{ June 23} & $\mathrm{~T}$ & 13.7 & 13.2 \\
\hline & & $\mathrm{L}$ & 10.4 & 9.7 \\
\hline & \multirow[t]{2}{*}{ June 30} & $\mathrm{~T}$ & 6.2 & 7.4 \\
\hline & & $\mathrm{L}$ & 8.3 & 7.3 \\
\hline & \multirow[t]{2}{*}{ July 7} & $\mathrm{~T}$ & 3.6 & 5.0 \\
\hline & & $\mathrm{L}$ & 6.4 & 5.3 \\
\hline & \multirow[t]{2}{*}{ July 21} & $\mathrm{~T}$ & 13.1 & 14.4 \\
\hline & & $\mathrm{L}$ & 13.5 & 12.2 \\
\hline & \multirow[t]{2}{*}{ July 28} & $\mathrm{~T}$ & 9.0 & 9.1 \\
\hline & & $\mathrm{L}$ & 9.4 & 8.9 \\
\hline \multirow[t]{8}{*}{ Preserve } & \multirow[t]{2}{*}{ June 11} & $\mathrm{~T}$ & 12.8 & 15.1 \\
\hline & & $\mathrm{L}$ & 13.0 & 12.6 \\
\hline & \multirow[t]{2}{*}{ June 25} & $\mathrm{~T}$ & 12.0 & 12.6 \\
\hline & & $\mathrm{L}$ & 12.0 & 11.3 \\
\hline & \multirow[t]{2}{*}{ July 9} & $\mathrm{~T}$ & 6.4 & 4.1 \\
\hline & & $\mathrm{L}$ & 7.5 & 4.8 \\
\hline & \multirow[t]{2}{*}{ July 21} & $\mathrm{~T}$ & 12.3 & 13.0 \\
\hline & & $\mathrm{L}$ & 12.5 & 11.6 \\
\hline
\end{tabular}

$\mathrm{T}=$ top soil, $2-12 \mathrm{~cm}$

$\mathrm{L}=$ lower soil, $12-22 \mathrm{~cm}$ 


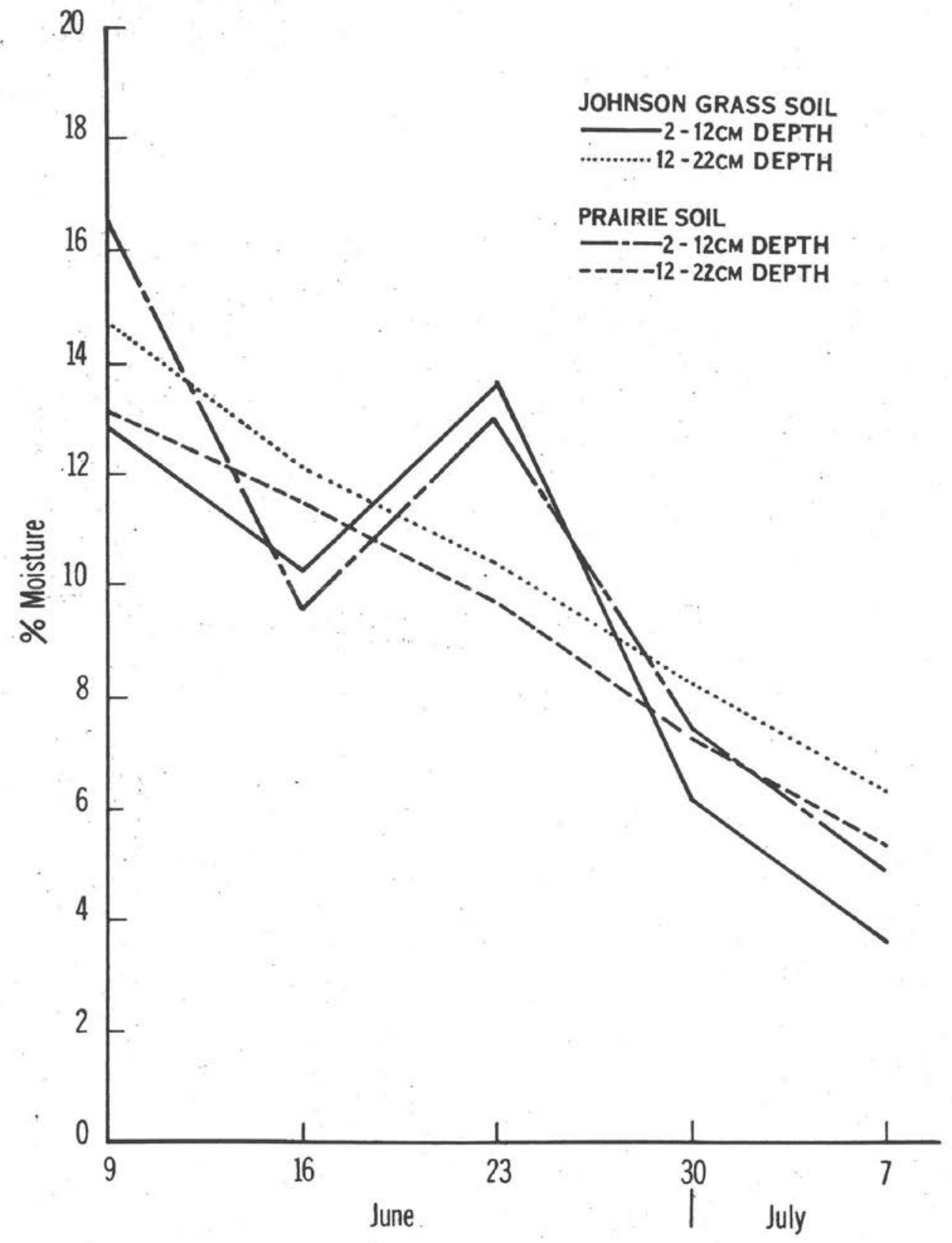

Figure 3 Average soil moisture by weight of 2 different soils at the 2-12 cm and 12-22 cm levels in June and July, 1970 at the Blackwell site. 


\section{Soil-Water Content under Different Tensions}

The prairie soil held more water at any given tension than the Johnson grass soil (Figure 4). This would be expected because it has more clay, silt, and organic matter than the disturbed Johnson grass soil. Plants would have to exert more energy at any given soil-water content to obtain water from the prairie soil compared to the Johnson grass soil. Conversely, at any given soil tension, the prairie soil would have more water available for use.

Since air-dried, disturbed soils were used, the actual values found for the soil moisture per soil pressure are not the same as would occur in the undisturbed soil profile.

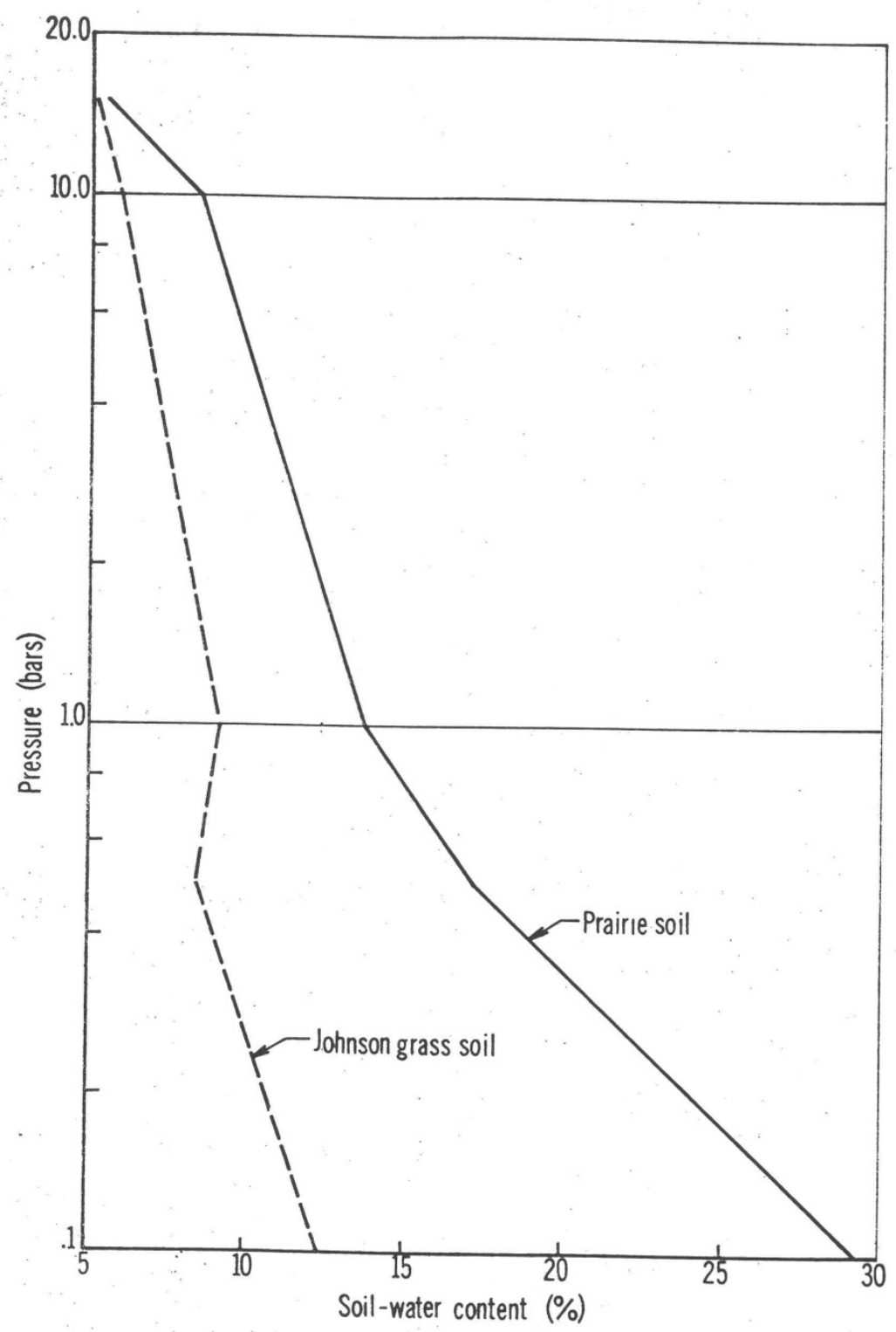

Figure 4 Soil-water content retained by air-dried soils, under different tensions (two replications per soil type). 


\section{Other Factors}

Both field sites were subjected to the same climate, wind, temperatures, and rainfall. Factors were not tested if they were believed to either favor the growth of Johnson grass over the prairie grasses or to exhibit no difference between the two habitats. Rice, Penfound, and Rohrbaugh (1960) reported that the nitrogen level of the soil influenced the rate of succession. Species later in succession (Andropogon and Sorghastrum) have a higher nitrogen requirement than plants earlier in succession. As both Schizachyrium scoparium and Sorghastrum nutans were present in the prairie studied, the nitrogen probably would be higher than in the disturbed habitat. Johnson grass was known to grow better in fertile soils with high nitrogen levels (Archer and Bunch 1953, Bennett and Merwine 1964). Huffman et al. (1963) stated that Johnson grass grew on roadsides, but more abundantly where soils were of better than average fertility. The higher nitrogen levels in the tall grass prairies, compared with soils earlier in succession, would actually be beneficial to growth of Johnson grass. Logically, nitrogen levels of the prairie soil would not restrict but encourage Johnson grass growth.

\section{Experiments}

\section{Seed Germination}

Despite many different methods to try to induce germination, no locally collected Johnson grass seeds germinated in any test. Other workers have found the seeds of Johnson grass to be highly dormant (Weir 1950, Anderson 1968, Taylorson and McWhorter 1969). No seeds were used in any later trials. Seeds from local Johnson grass populations probably require a long after-ripening period.

\section{Soil Preference in a Laboratory Situation}

Initially, fewer plants emerged in the prairie soil than in the other soils, sand and disturbed Johnson grass soil (Figure 5). This trend was not statistically significant, but was present in all replications. After the initial 2 weeks, the number of plants per flat was consistently higher in the prairie soil than in the others. The difference in the average total plant emergence after 41 days between the prairie and disturbed soil was significant only at the 20 percent level with a t-test. No significant difference was found between sand (control) and the disturbed habitat soil. Visibly, plants grown in the prairie soil were greener and taller than in the other two treatments. The increased vigor was likely due to the higher fertility of the prairie soil.

\section{Growth in Disturbed and Undisturbed Field Plots}

Study of Johnson grass planted in the field under 2 types of conditions revealed a difference in emergence and growth. In the undisturbed or natural plots, 70 rhizomes were planted, with 60 in the prairie and 10 in the Johnson grass stand. No plants emerged (Table IV). Of the 70 rhizome segments planted in the disturbed or modified plots, in the same proportions given above, 5 were alive at the end of the summer: 3 in the Johnson grass stand and 2 in the prairie. The 3 plants in the Johnson grass stand were divided between the two replications. One plant emerged shortly after planting, while emergence was delayed almost a month in the case of the other two. The cause of the difference in emergence time was unknown, but noticeable differences were seen in the dry weight and number of new rhizome segments. In the prairie, 4 plants actually emerged, in the same replication, but only 2 survived the summer.

In the disturbed sites, with all plants and litter removed, the soil was exposed to increased radiation. This produced greater heating and drying than in a comparable soil 


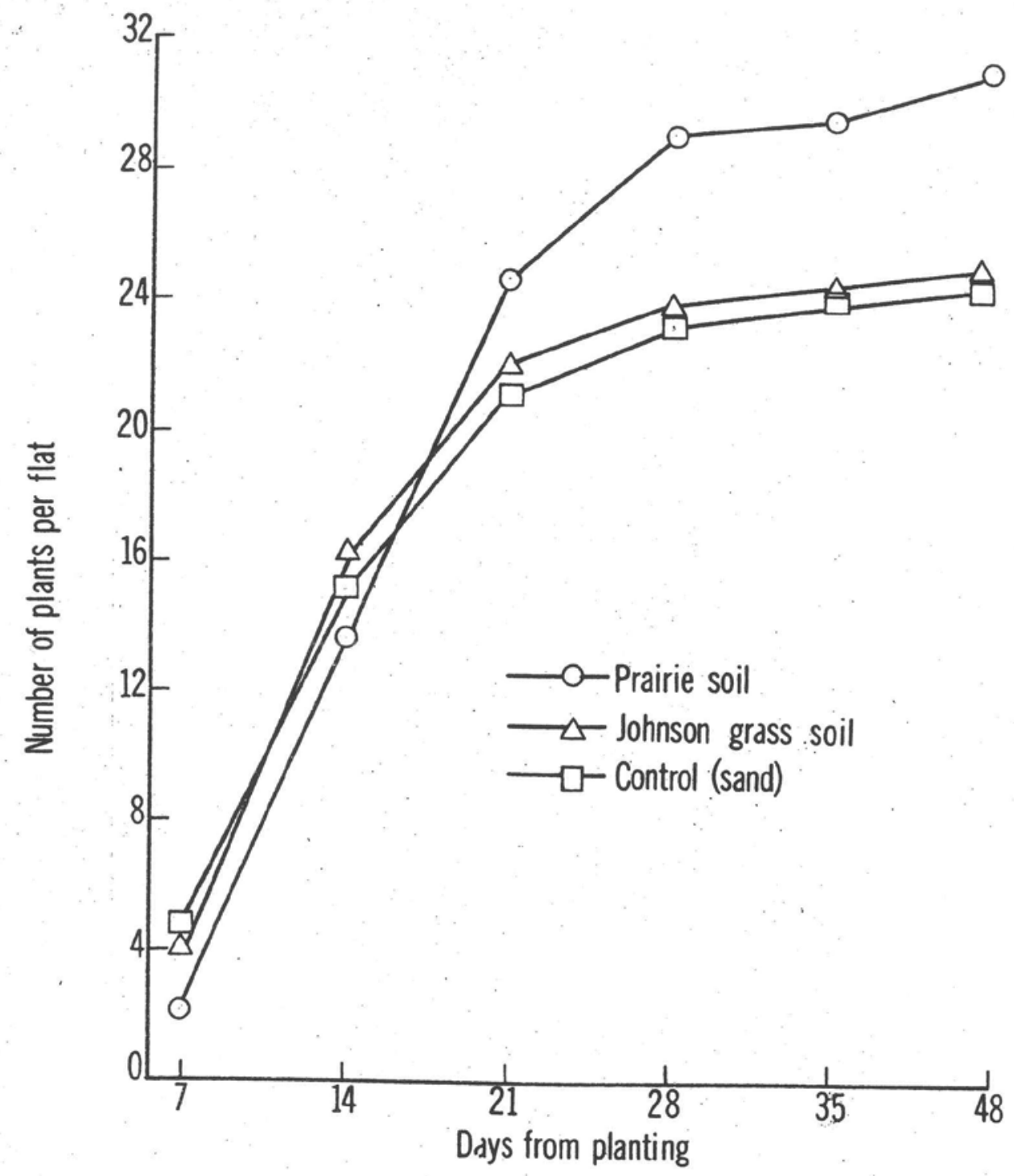

Figure 5 Effect of soil type on emergence of Johnson grass from rhizomes in flats in the greenhouse (three replications per soil type). 
Table IV Comparison of field grown Johnson grass plants in 2 areas after one summer of growth from rhizome segments (May-September 1971)

\begin{tabular}{|c|c|c|c|c|c|c|c|}
\hline Soil & Treatment & Rep. & $\begin{array}{l}\text { Survival/ } \\
\text { planted }\end{array}$ & $\begin{array}{l}\text { Percent } \\
\text { survived }\end{array}$ & $\begin{array}{c}\text { Plot } \\
\#\end{array}$ & $\begin{array}{c}\text { Dry } \\
\text { wt. (g) }\end{array}$ & $\begin{array}{c}\text { New } \\
\text { rhizome } \\
\text { nodes }\end{array}$ \\
\hline
\end{tabular}

$\underline{\text { Blackwell }}$

$\begin{array}{llllcccc}\text { Johnson } & \text { Natural } & 2 & 0 / 10 & 0 & & - & - \\ \text { grass } & \text { Modified* } & 2 & 3 / 10 & 30 & 1 & 1.12 & 7 \\ & & & & & & 1.30 & 6 \\ & & & & & 2 & 7.10 & 29\end{array}$

\begin{tabular}{|c|c|c|c|c|c|}
\hline Prairie & Natural & 4 & $0 / 20$ & 0 & . \\
\hline
\end{tabular}

\section{$\underline{\text { Preserve }}$}

Prairie

$\begin{array}{lll}\text { Natural } & 8 & 0 / 40 \\ \text { Modified }^{*} & 8 & 2 / 40\end{array}$

0

6.7
$1 \quad 0.04$

0.35
7

6

29

\section{*Vegetation removed, soil sieved}

surface protected by layers of litter and plants. A crust formed over the surface in both the Blackwell prairie plots and on the plots in transect \#1 in the Preserve. These two areas were the harshest places in the experiment for Johnson grass to grow. Yet it was only in the Preserve prairie, transect \#1 that Johnson grass even emerged in a prairie. In the other 3 transects, disturbed plots were soon shaded by nearby rapidly growing prairie grasses. The soil was shaded, cooler, and retained more moisture.

The number of plants emerging within a prairie and a Johnson grass stand were similar, but differences in size, dry weight, and number of new rhizome nodes were striking (see Table IV). Those in the Johnson grass stand were visibly taller, greener, and seemed healthier than those in the prairie. Those in the prairie were stunted and had yellowish foliage. In the prairie, the plants had no new rhizome initiation, while those in the Johnson grass stand were actively producing new rhizome nodal segments.

Johnson grass growth was greatly enhanced by disturbance of the prairie soil and removal of the vegetation. The Johnson grass plants in the prairie were so stunted that survival for much longer was doubtful. Few roots were found on observation and those were very small. The reduced food storage would reduce the chances of establishment. A limited growth of Johnson grass in the prairie was obtained with removal of grasses in the immediate area.

This experiment was handicapped by not being initiated until May. During May, the soil temperatures were approaching $30^{\circ}$ $\mathrm{C}$, improving the soil temperature for growth compared with cooler soil temperatures earlier in the year. However, 
the plants had very little time to develop a root system before the hot summer conditions arrived, which probably resulted in the low survival observed.

\section{Interference Experiment}

A box experiment was conducted to compare growth and emergence of Johnson grass under different conditions. In the control boxes, conditions for growth would not seem optimal. Soil was directly exposed to the sun. Heating and drying of the soil surface formed a hard crust over the soil surface. The crust served to conserve soil moisture, but also made it harder for the plants to penetrate. Growth did not seem to be restricted, as the average dry weight was higher than most of the other treatments (Table V, Figure 6). Emergence was higher than in any other treatment.

The light shade provided better conditions for Johnson grass growth. The soil retained more moisture, and less hardening of the surface occurred than in the control. Overall, those plants were the tallest and most vigorous. The thin cloth was not a barrier restricting growth. Most plants grew up through the cloth.

The cloth in the medium shade treatment was a minor barrier restricting growth in height. In two replications, the tips of a few blades reached the cover and were bent. In replication \#2, the plants pushed off the cover and grew vigorously in the increased sunlight. If the average dry weight was found for the medium shading without the one strikingly different replication, the average dry weight would only be $0.3 \mathrm{~g}$ per plant. This would make it similar to the average values in the dark and litter treatments (see Figure 6).

Emergence was low under the deep shade, perhaps due to decreased light or temperature. The few plants that appeared were small. The growth rate was slow. None grew tall enough for the solid cloth to act as a physical barrier during the short period of the experiment. The greatly decreased light intensity seemed to have a definite slowing effect on growth. Ryle (1967) found that ryegrass responded to shading with slower growth. Some growth of Johnson grass was obtained in all three shading treatments. Fewer plants grew with greatly decreased light, as would be found at the soil surface of prairies with heavy build-up of litter. Light was important, but would not prevent growth of Johnson grass within a prairie.

The leached litter produced shade as well as mulching and possible chemical effects. The soil remained more moist than in any but the deep shade treatment. The plants appeared above the soil surface in the boxes with the leached litter cover over a week later than in the other treatments. Variation in appearance was evident. Of the 15 rhizomes planted, 11 plants grew. A few plants appeared green and healthy, although they seemed to be growing more slowly than those in the control or with light shading. The majority of the plants were yellow-green in color and appeared stunted or at least growth was retarded. The plants emerged above the soil surface but little additional growth occurred. Two plants were thin or etiolated. Simple reduction in light intensity may explain the etiolated condition, but would not satisfactorily explain the stunting and discoloration of the Johnson grass plants under the litter. The "weight" of the litter did not prevent the plants from growing, as suggested by Weaver and Rowland (1952). Tips of a few plants were appearing above the litter. The old litter seemed to retard growth, but not prevent it.

Johnson grass plants in aerial contact with the prairie grasses were smaller with slower growth than the control or light shade treatment. The plants seemed stunted. Digging up the soil after the experiment showed no root invasion by one into the area of the other. The Johnson grass plants that did grow were greenish-yellow. 
Table V Dry weight in grams and emergence of Johnson grass plants grown for 35 days from rhizomes

\begin{tabular}{|c|c|c|c|c|c|c|c|c|c|c|c|c|c|c|c|c|c|c|}
\hline & \multicolumn{3}{|c|}{ Control } & \multicolumn{3}{|c|}{ Light shade } & \multicolumn{3}{|c|}{ Medium shade } & \multicolumn{3}{|c|}{ Deep shade } & \multicolumn{3}{|c|}{ Litter mulch } & \multicolumn{3}{|c|}{ Competition } \\
\hline & 1 & 2 & 3 & 1 & 2 & 3 & 1 & 2 & 3 & 1 & 2 & 3 & 1 & 2 & 3 & 1 & 2 & 3 \\
\hline \multirow{5}{*}{$\begin{array}{l}\text { Individual } \\
\text { weights }\end{array}$} & 1.9 & 0.2 & 0.2 & 1.1 & 0.4 & \multirow[t]{5}{*}{0.5} & \multirow[t]{5}{*}{0.4} & 0.6 & 0.1 & \multirow[t]{5}{*}{0.3} & \multirow[t]{5}{*}{0.0} & \multirow{5}{*}{$\begin{array}{l}0.1 \\
0.4\end{array}$} & \multirow{5}{*}{$\begin{array}{l}0.6 \\
0.4\end{array}$} & 0.3 & 0.3 & 0.05 & 0.1 & \multirow[t]{5}{*}{0.7} \\
\hline & 0.9 & 0.4 & 0.5 & 0.9 & 1.2 & & & 1.1 & 0.3 & & & & & 0.9 & 0.2 & 0.5 & 1.0 & \\
\hline & 0.2 & 0.9 & 0.5 & 2.3 & 0.6 & & & 2.1 & 0.1 & & & & & 0.4 & 0.1 & 0.45 & & \\
\hline & \multirow{2}{*}{\multicolumn{3}{|c|}{$\begin{array}{l}0.6 \\
0.5\end{array}$}} & & \multirow[t]{2}{*}{0.7} & & & & \multirow[t]{2}{*}{0.4} & & & & & \multirow[t]{2}{*}{0.4} & 0.2 & & & \\
\hline & & & & & & & & & & & & & & & 0.2 & & & \\
\hline Means & 0.8 & 0.5 & 0.5 & 1.4 & 0.7 & 0.5 & 0.4 & 1.3 & 0.2 & 0.3 & 0.0 & 0.2 & 0.5 & 0.5 & 0.2 & 0.3 & 0.6 & 0.7 \\
\hline Grand means & & 0.6 & & & 0.9 & & & 0.6 & & & 0.3 & & & 0.4 & & & 0.5 & \\
\hline \multicolumn{19}{|l|}{$\begin{array}{l}\text { Emergence } \\
\text { percentage }\end{array}$} \\
\hline Means & & 80 & & & 53 & & & 53 & & & 20 & & & 73 & & & 40 & \\
\hline
\end{tabular}




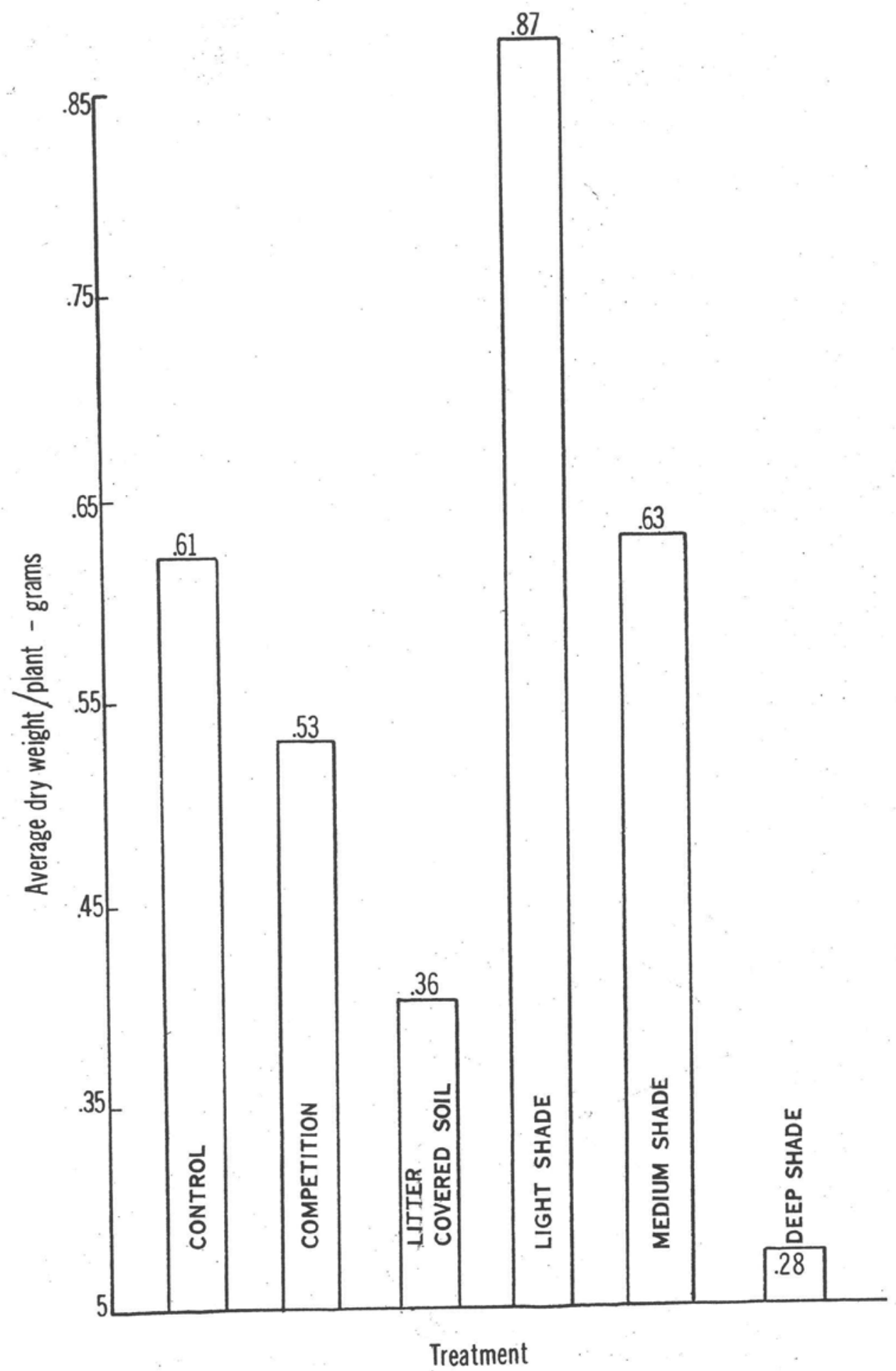

Figure 6 Dry weights of Johnson grass plants grown from rhizomes (three replications per condition). 
One rhizome produced several new segments laterally in the direction away from the prairie grasses before emergence at the edge of the box. Why the rhizome grew away from the prairie grass side was unknown. After appearance above ground, little increase in height was recorded. Most of the dry weight was due to the formation of new rhizome segments rather than leaves. No new rhizome segments were produced laterally in any other replication or treatment. Without the additional weight due to the new rhizome segments on that one plant, the average dry weight in the competition boxes would be lower and closer to the average dry weight in the litter treatment. The presence of the prairie grasses within a few centimeters seemed to have as much affect as did medium and deep shading, though the Johnson grass plants were still fully exposed to the sun.

The difference in average dry weight per treatment proved significant at an 0.01 level with an F-test. Variation within treatments was evident, with the few replications used. Fluctuation in percent of emergence between treatments was not statistically significant in any reasonable confidence range due to the variation within treatments. More replications would be necessary to establish any differences in emergence between treatments.

\section{Effect of Plant Leachate on Growth}

In the two treatments watered with a leachate, fewer plants emerged, the size of the plants was smaller, and increase in height was slower than in the controls watered with distilled water (Figures 7, 8). No difference was detected between the effects of the two types of litter leachates. Those plants watered with distilled water grew more vigorously than in the other treatments. The experiment was continued after the watering with leachate was stopped to determine if the rhizomes were killed or inhibited. When the leachate was no longer applied, many new plants appeared. An increased growth rate was evident.

\section{SUMMARY AND CONCLUSION}

Johnson grass (Sorghum halepense) grows abundantly in disturbed areas south of latitude $40^{\circ}$. In this area, it grows in disturbed roadsides and disturbed fields: beside, but not in, tall grass prairies. Johnson grass was usually growing in areas where prairie plants had been disturbed or destroyed, as along roadsides. Many stands of Johnson grass along roadsides were areas of frequent disturbances. Soil differences between the prairie and the Johnson grass stands seemed to be the result of disturbances, not natural differences. The prairie soils had a slightly different ratio of particle size and texture. The soil $\mathrm{pH}$ and particle densities were similar. However, the prairie soils had considerably more organic matter and were able to retain more soil moisture at any one soil tension than in the other soil. Rice, Penfound, and Rohrbaugh (1960) found that prairies with species later in succession had higher nitrogen levels than soils with vegetation of the weed stage.

Archer and Bunch (1953) reported that Johnson grass grew well on fine sandy loams, but did not thrive on poor depleted or deep sandy soils. Huffman et al. (1963) reported Johnson grass abundant on roadsides and open areas where soils were of better than average fertility. Based on physical characteristics of the two soils, the prairie would seem more favorable to Johnson grass growth than the disturbed habitat in which it grows. In laboratory tests, Johnson grass grew better in the prairie soil than in its own soil. The prairie soil did not inhibit or limit Johnson grass growth.

In the field, other factors influenced Johnson grass growth. In nature, Johnson grass grew in disturbed sites and not in the prairies. Growth was obtained in a prairie only with disturbance and removal of prairie 


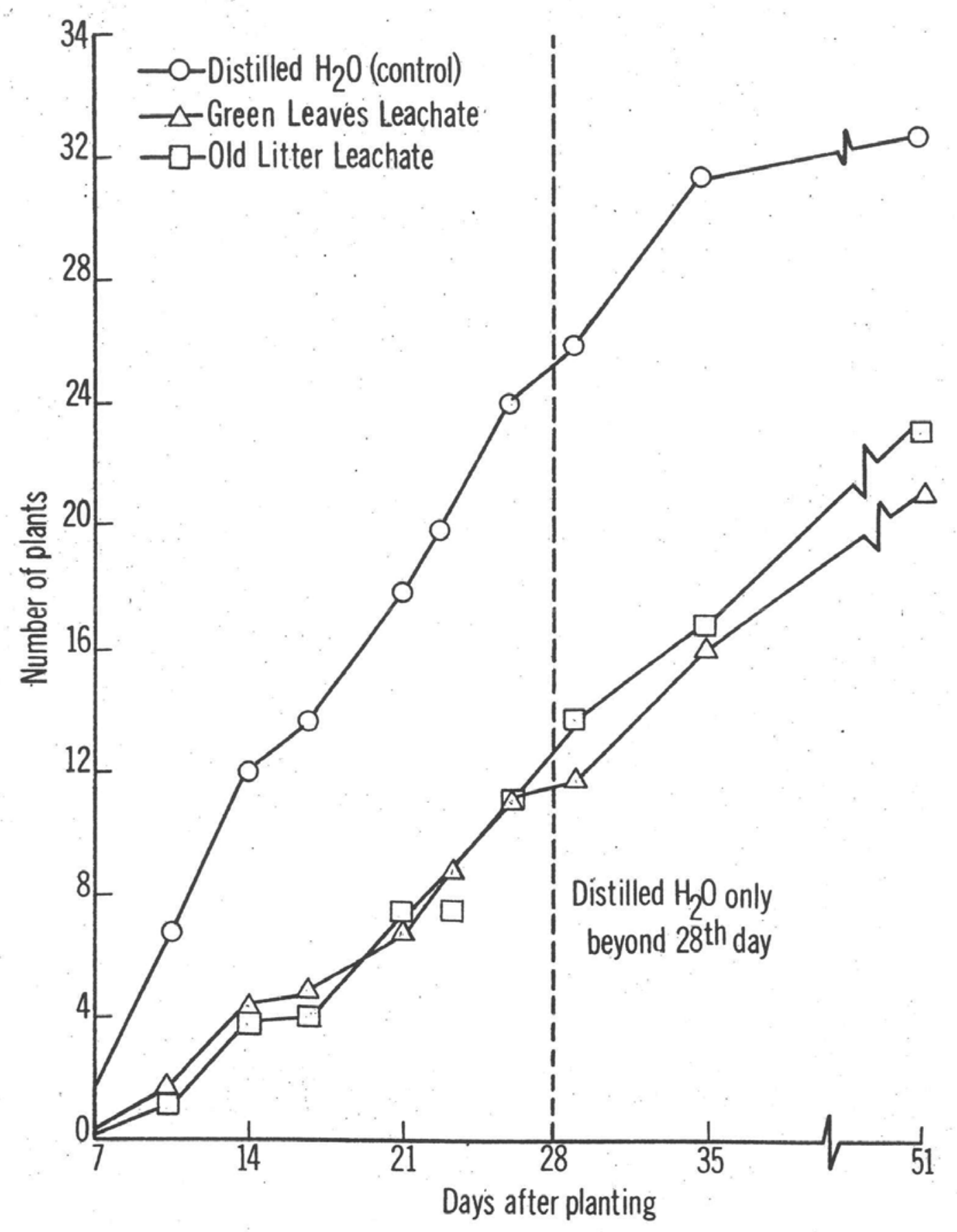

Figure 7 Emergence of Johnson grass plants from rhizomes under treatment with prairie grass leaf leachate (four replications per treatment). 


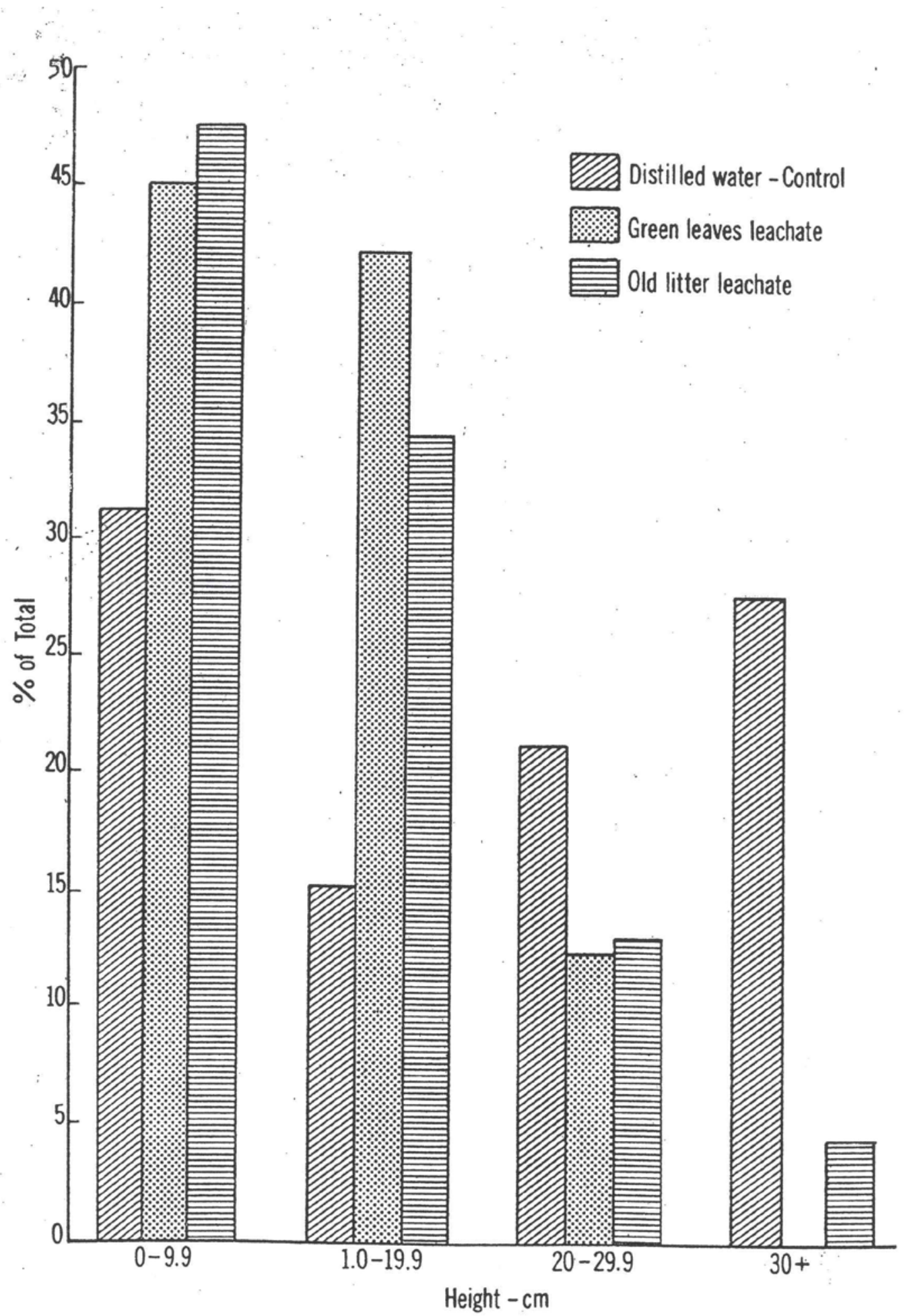

Figure 8 Height distribution of Johnson grass plants grown from rhizomes under treatments with prairie grass leaf leachate. 
plants and litter. Johnson grass grew in a small, disturbed plot in a prairie but was stunted. Continued survival and establishment of the few Johnson grass plants that did grow were very doubtful. No Johnson grass growth was detected in the undisturbed or natural prairie plots.

Similar results were obtained with Johnson grass growth in Johnson grass stands. The only plants that emerged were in the disturbed or modified sites. The fact that none emerged in the plots in undisturbed Johnson grass stands might be expected. Abdul-Wahab and Rice (1967) reported that Johnson grass produced several inhibitory chemicals. Some of these inhibited its own seedling and rhizome bud growth. Upon observation, no young Johnson grass shoots were found within the stand. Numerous young plants were found along the edge of the stand spreading into the dirt road, but none were spreading out into the prairie side. The question remained of why no Johnson grass plants emerged in the undisturbed prairie.

Light intensity influenced Johnson grass growth. In the field, the only emergence was in the plots with either full sunlight or light shading. The most vigorous growth in the box experiment was obtained with light shading. With shading approximating that found at ground level in a prairie with heavy litter build-up, reduced growth of Johnson grass was noticed. Yet the dry weight of the Johnson grass plants after a whole season of growth in the disturbed prairie plots was considerably less than the dry weight of those under light shade after only 1 month of growth. The reduced emergence under the deep shading would not constitute exclusion. The leached litter produced average dry weights similar to those with deep shade but without the lower emergence. Aerial interference with prairie plants lowered both the average dry weight and emergence number of Johnson grass.

The few Johnson grass plants that grew when introduced in the small disturbed prairie plots were small, weak, and stunted. In a box experiment, the Johnson grass plants growing near the prairie grasses were smaller and slightly discolored. Evidence suggests that the hypothesis that prairie grasses were producing some chemical inhibiting the growth of Johnson grass might be valid. The production of growth inhibiting substances by higher plants is not unknown. The production of these substances, termed allelopathic substances, appears to be widespread. Risser (1969) felt that allelopathic substances might play a part in formation and maintenance of vegetative patterns.

Some plants produce allelopathic substances that are known to be inhibitory to their own growth, as in the cases of Bromus inermis, Helianthus pauciflorus, $H$. annuus, and Sorghum halepense (Benedict 1941, Cooper and Stoesz 1931, Curtis and Cottam 1950, Wilson and Rice 1968, Abdul-Wahab and Rice 1967). Weaver and Rowland (1952) noted that the prairie grasses grew better with the removal of a heavy build-up of prairie mulch. They also remarked on the lack of understory herbs in a prairie with a heavy build-up of litter. An allelopathic substance in the grass litter would help explain the lack of understory vegetation. If the substance was short-lived once released or easily leached from shallow nursery flats, this would help explain the lag in emergence of Johnson grass in prairie soil or under prairie litter in previous experiments.

Since the inhibitory effect on Johnson grass was seen in the absence of root contact and in the presence of aerial parts, the leaves seemed a likely source. Something was present in the mixed leaves of little bluestem and Indian grass which inhibited bud growth of a Johnson grass rhizomal segment and the rate of plant growth. The inhibitory substance was present in both green leaves and dead litter. This indicated that sufficient quantity was present in the leaves to allow storage and slow release. 
The implication existed that the inhibitory substance leached from the prairie grass might be influential in formation or maintaining of vegetative patterns in the prairie. Sagar and Harper (1961) showed that the presence and vigor of grasses in a community played a role in determining presence or absence of Plantago spp. Putwain and Harper (1970) concluded that the grasses were responsible for limiting population size of Rumex L. spp. The prairie grasses, little bluestem and Indian grass, seemed to play a role in restricting the growth of Johnson grass to along roadsides and out of the prairies.

\section{ACKNOWLEDGMENTS}

The author wishes to express appreciation to her major adviser, Dr. J. K. McPherson, for his guidance, helpful suggestions, and assistance in the preparation of this manuscript.

Gratitude is expressed to her committee members, Drs. George L. Barnes and Paul E. Richardson, for their advice, aid, and constructive criticism.

The author wishes to thank Dr. James M. Davidson, Associate Professor of Agronomy, for his invaluable assistance with the soil analysis portion of this paper.

Sincere thanks are expressed to Dr. R. G. Price for his assistance in obtaining space for conducting the interference experiments.

Special thanks are expressed to $\mathrm{Mr}$. Frank Hulnik, Mr. Eugene Burris, Mr. Richard Semtner, and Mr. Richard Vernon, students at Oklahoma State University, for their assistance in this investigation.

Appreciation for personal financial support is expressed to the National Science Foundation for a Graduate Traineeship award.

Very special appreciation is extended to the author's husband, Paul, for his understanding, patience, encouragement, and assistance in the course of this study.

\section{LITERATURE CITED}

Abdul-Wahab, Ahmad and Elroy L. Rice. 1967. Plant inhibition by Johnson grass and its possible significance in old-field succession. Bulletin of Torrey Botanical Club 94:426-497.

Ahlgren, Gilbert H. 1956. Forage Crops. New York: McGraw-Hill Book Co.

Anderson, Robert N. 1968. Germination and Establishment of Weeds for Experimental Purposes. New York: W. F. Humphrey.

Anderson, L. E., A. P. Appleby, and J. W. Wescloh. 1960. Characteristics of Johnson grass rhizomes. Weeds 8:402406.

American Society for Testing and Materials. 1958. Procedures for testing soils. Philadelphia.

Archer, Sellers G. and Clarence E. Bunch. 1953. The American Grass Book, a Manual for Pasture and Range Practices. Norman: University of Oklahoma Press.

Beal, William James. 1887. Grasses of North America. Lansing (MI):Thorp and Godfrey.

Benedict, H. M. 1941. The inhibitory effect of dead roots on the growth of brome grass. Journal of American Society of Agronomy 33:1108-1109.

Bennett, Hugh W. and N. C. Merwine. Legumes in Johnson grass. Mississippi Agricultural Extension Station Bulletin 698.

Betz, Robert F. and Marion H. Cole. 1969. The peacock prairie: A study of a virgin Illinois mesic black soil prairie forty years after initial study. Transactions of the Illinois State Academy of Science 62:44-53.

Black, C. A., ed. 1965. Methods of Soil Analysis Part I. Madison (WI): American Society of Agronomy.

Black, C. C., J. M. Chen, and R. H. Brown. 1969. Biochemical basis for plant competition. Weed Science 17:338-344.

Bonner, J. 1950. The role of toxic substances in the interaction of higher plants. Botany Review 16:51-65. 
Booth, W. E. 1941. Revegetation of abandoned fields in Kansas and Oklahoma. American Journal of Botany 28:415-422.

Clements, Frederic E. and Vistor E. Shelford. 1939. Bio-Ecology. New York: John Wiley and Sons.

Cooper, W. S. and A. D. Stoesz. 1931. The subterranean organs of Helianthus saaberrimus. Bulletin of Torrey Botanical Club 58:67-72.

Costello, David F. 1969. The Prairie World. New York: Thomas Y. Crowell.

Curtis, J. T. and G. Cottam. 1950. Antibiotic and autotoxic effect in prairie sunflower. Bulletin of Torrey Botanical Club 77:187191.

deLaubenfels, David J. 1970. A Geography of Plants and Animals, Dubuque (IA): William C. Brown.

Ehrenreich, J. H. and J. M. Aikman. 1963. An ecological study of the effects of certain management practices on native prairie in Iowa. Ecological Monographs 33:113-130.

Evans, L. T. 1964. Control of Reproduction Cycles in Grasses by Environmental Conditions. In: Barnard, C., ed. Grasses and Grasslands. New York: MacMillan.

Friend, D. J. C. 1966. The effect of light and temperature on the growth of cereals. In: Milthorpe, F.L. and J.D. Ivins, eds. The growth of cereals and grasses. Proceedings of the Twelfth Easter School in Agricultural Science. 181-199.

Grossman, Shelly, Mary Louise Hamelot, and John N. Hamelot. 1969. Our Vanishing Wildness. New York: Madison Square Press.

Harper, J. L. 1964a. The individual in the population. Journal of Ecology 52:149-158.

Hicks, R. D. and O. H. Fletchell. 1967. Control of Johnson grass (Sorghum halepense) in corn. Weeds 15:16-20.

Hitchcock, A. S. 1922. A Text-Book of Grasses, with Especial Reference to the Economic Species of the United States. New York: MacMillan.
Huffman, George G., Tyson A. Cathy, and James E. Humphrey. 1963. Parks and scenic areas in the Oklahoma Ozark. Oklahoma Geological Survey Guide Book XII.

Hull, Richard J. 1970. Germination control of Johnson grass rhizome buds. Weed Science 18:118-121.

Hylander, Clarence J. 1966. Wildlife Communities from the Tundra to the Tropics in North America. Boston: Haughton.

Kingsburg, John M. 1965. Deadly Harvest, a Guide to Common Poisonous Plants. New York: Holt, Rinehart, and Winston.

Kleifeld, Y. 1970. Combined effect of Trifluralin and MSMA on Johnson grass control in cotton. Weed Science 18:16-18.

Leonard, O. A. and V. C. Harris. 1952. The effects of aliphatic hydrocarbons on the hypocotyls of cotton and soybeans and on the shoots of nutgrass, Johnson grass, and other weeds by the directional spray technique. Weed Science 1:256-273.

McWhorter, C. G. 1961. Morphology and development of Johnson grass plants from seeds and rhizomes. Weeds 9:558562.

Millhollon, Rex W. 1970. MSMA for Johnson grass control in sugarcane. Weed Science 18:333-337.

Mitchell, K. J. 1953a. Influence of light and temperature on the growth of ryegrass (Lolium spp.). I. Pattern and vegetative development. Physiologia Plantarum 6:2146.

Mitchell, K. J. 1953b. Influence of light and temperature on the growth of ryegrass (Lolium spp.). II. The control of lateral bud development. Physiologia Plantarum 6:425-443.

Muenscher, Walter Conrad. 1939. Poisonous Plants of the United States. New York: MacMillan.

Muller, Cornelius H. 1966. The role of chemical inhibition (allelopathy) in vegetational composition. Bulletin of Torrey Botanical Club 93:332-351. 
Muller, Cornelius H., W. H. Muller, and B. L. Haines. 1964. Volatile growth inhibitors produced by aromatic shrubs. Science 143:471-473.

Muller, Cornelius H., Ronald B. Hanawalt, and James K. McPherson. 1968. Allelopathic control of herb growth in the fire cycle of California chaparral. Bulletin of Torrey Botanical Club 95:225231.

Munz, Philip A. 1963. A California Flora. [Berkeley]: University of California Press.

Nester, R. P. 1967. Johnson grass (Sorghum halepense) control in soybeans. Soybean Digest 27:17.

Odum, Eugene P. 1971. Fundamentals of Ecology. Philadelphia: W. B. Saunders.

Parenti, Robert L. and Elroy L. Rice. 1969. Inhibitional effects of Digitaria sanguinalis and possible role in old-field succession. Bulletin of Torrey Botanical Club 96:70-78.

Penfound, W. T., M. C. Jennison, and J. S. Shed. 1965. Replacement of a population of Johnson grass by a vineforb community. Proceedings of the Oklahoma Academy of Science 45:40-41.

Petty, R. O. and M. T. Jackson. 1966. Plant communities. Indiana Academy of Science Sesquicentennial Vol. 1816-1966:264-296.

Pickering, S. 1917. The effects of one plant on another. Annals of Botany 31:181-187.

Putwain, P. D. and J. L. Harper. 1970. Studies in the dynamics of plant populations. III. The influence of associated species on populations of Rumex acetos $\mathrm{L}$. and $\mathrm{R}$ acetosella $\mathrm{L}$. in grassland. Journal of Ecology 51:251-264.

Rice, Elroy L. 1964. Inhibition of nitrogenfixing and nitrifying bacteria by seed plants. I. Ecology 45:824-837.

Rice, Elroy L., William T. Penfound, and L. M. Rohrbaugh. 1960. Seed dispersal and mineral nutrition in succession in abandoned fields in central Oklahoma. Ecology 41:224-228.

Risser, Paul G. 1969. Competitive relationships among herbaceous grassland plants. Botanical Review 35:251289.

Ryle, G. T. A. 1967. Effect of shading on infloresence, size, and development in temperate perennial grasses. Annual of Applied Biology 59:297-307.

Sagar, G. R. and J. L. Harper. 1961. Controlled interference with natural populations of Plantago laneolata, P. major, and P. media. Weed Research 1:163-176.

Sears, Paul B. 1969. Lands Beyond the Forest. [Upper Saddle River (NJ)]: PrenticeHall.

Taylorson, R. B. and C. G. McWhorter. 1969. Seed dormancy and germination in ecotypes of Johnson grass. Weed Science 17:359-361.

Tester, Wiley C. and Grover McCormick. 1954. Germination of Johnson grass, results of tests made by the Arkansas State Plant Board. Proceedings of the Association of Official Seed Analysts 44:9699.

Tukey, H. B. 1969. Implications of allelopathy in agricultural plant sciences. Botanical Review 35:1-16.

Vesey-FitzGerald, Desmond Foster. 1970. The origin and distribution of valley grasslands in east Africa. Ecology 58:5175.

Vogl, Richard J. 1964. The effects of the vegetational composition of brackengrasslands. Transactions of Wisconsin Academy of Science, Arts, and Letters 53:6782.

Vogl, W. E. and A. T. Bjugsted. 1968. Effects of clipping on yields and tillering of little bluestem, big bluestem, Indian grass. Journal of Range Management 21:136140.

Weaver, J. E. 1968. Prairie Plants and Their Environment, a Fifty-Year Study in the Midwest. Lincoln: University of Nebraska Press.

Weaver, J. E. and T. F. Fitzpatrick. 1934. The prairie. Ecological Monographs 4:109295. 
Weaver, J. E. and N. W. Rowland. 1952. Effects of excessive natural mulch on development, yield, and structure of native grassland. Botanical Gazette 114:119.

Weir, H. L. 1959. Germination of Johnson grass. Proceedings of the Association of Official Seed Analysis 49:82-83.

Wheeler, W. A. and D. P. Hill. 1957. Grassland Seeds: A Handbook of Information About the Grass and Legume Seed Used for Forage, Pasture, Soil Conservation, and Other
Turf Planting in the United States. Princeton: D. Van Nostrand.

Wiese, A. F. 1968. Johnson grass: Control with Dalapon and Nethanearsonate herbicides. Texas Agricultural Experiment Station MP-883.

Wilson, R. E. and Elroy L. Rice. 1968. Allelopathy as expressed by Helianthus annuus and its role in old-field succession. Bulletin of Torrey Botanical Club 95:432-448. 